\title{
ANALYSIS OF EXPECTATIONS ON ELECTRONIC GROCERY SHOPPING FOR POTENTIAL CUSTOMER SEGMENTS 4
}

\author{
HEIKKILÄ JUKKA \\ KALLIO JUKKA \\ SAARINEN TIMO \\ TUUNAINEN VIRPI KRISTIINA \\ Helsinki School of Economics, Electronic Commerce Institute \\ P.O. Box 1210, FIN-00101 HELSINKI, Finland \\ heikkila@hkkk.fi \\ jkallio@hkkkfi \\ saarinen@hkkk. $i$ \\ tuunaine@hkkk.fi
}

\begin{abstract}
The special nature of groceries, especially perishables, challenges the possibilities of digital channels i.e. computers and networks to improve customer service. We report the findings of theme interviews on the potential of electronic commerce (EC) of groceries with 33 experts of grocery industry and EC, most of them senior executives, in 23 organisations in Finland during the Autumn of 1997. The specific areas of interest in the study are the predicted volume of EC in grocery shopping, the most potential customer segments, the anticipated benefits of EC to customers, and supplier strategies and infrastructure alternatives. Benefits of EGS (electronic grocery shopping) are analysed for three selected potential customer groups in terms of phases in consumer buying process as well as two different infrastructure solutions. It seems that an EGS build on top of current grocery industry infrastructure can only satisfy one major consumer group. In order to gain momentum EGS needs a dedicated infrastructure within which logistic efficiency can be increased.
\end{abstract}

o

\section{INTRODUCTION}

This article reports the results of a study on the electronic commerce (EC) of daily grocery goods on the Net. The study of grocery shopping is of value, because groceries seem to be one of the most difficult objects of trade for electronic commerce: material flows are distinct from information flows, the number of potential customers is huge, and an average purchase consists of many items (e.g. Gould and Silberzahn, 1996). The diffusion of electronic trade of groceries is not only subject to customer behaviour but to national and trade area regulation, irreversible investments in logistics by current suppliers, and to the existence of standardised platforms for the electronic transactions, e.g. UN/EDIFACT. This is in contrast to the commerce of digital products (such as information services, computer games, video and gambling) that are easily accessible throughout the world, as the information about the product and the product itself are in digital format (Choi et al., 1997). EC of daily groceries is also more difficult than electronic commerce of many other physical products like books or clothing, because groceries are prone to spoil, if not handled properly.

The Finnish case highlights this issue exceptionally well, because the technology is readily available to the Finnish customers: most companies and many households are linked to Internet. More than one third of households in Finland already have computers, and the host to population ratio is 87.3 per 100000 habitants, the highest in the world (TELMO $\left.{ }^{5}, 1997\right)$. The density of servers and capacity of telecommunications lines are estimated to be high enough to serve the customer population. Yet, the consumer services on the networks have not kept up with the technological possibilities: a fact that has urged us to launch this study together with the Ministry of Trade (Kallio et al. 1997).

The specific areas of interest of this article are the predicted volume of EC in daily grocery shopping, the best potential customer segments, the anticipated benefits of EC to customers, and suppliers strategies and infrastructural choices. We addressed the topics by theme interviewing the key informants from the supply side of daily shopping: representatives of current producers, suppliers, and potential service providers to the grocery market.

Before going further, we must ask: What is electronic commerce of daily grocery goods? To most of the interviewees it is about ordering a basket of commodities over digital network. However, there has been mail

${ }^{4}$ This article is based on the paper presented in European Conference on Information Systems, Aix-en-Provence, France, on the $7^{\text {th }}$ of May, 1998 (Heikkilä et al., 1998a)

5 TELMO ry, The Finnish Association for Interactive Network Services, was established in 1992 to promote the development of telematic services in Finland. TELMO operates as a co-operative forum and working organisation of its members: the users of the services, service providers, network operators, system vendors and governmental bodies. 
ordering and other means e.g. electronic devices such as phones, faxes, etc., available for a long time. But after easy access to Internet, it is feasible to provide information about products, place orders, etc. in a profitable manner. This is because all the information is in digital format for further analysis and processing for the development of future value-added services.

The article is organised as follows: Firstly we describe the research methodology: selection of key informants, the themes, and the data collection procedure. We then report the findings of the study in the context of trade of grocery goods in Finland. In the following section we outline the EC services in the different phases of consumer's shopping process, and then describe EGS and its benefits from the point of view of three selected potential customer groups. Supplier strategies and two infrastructures as the basis for EGS are also discussed. The potential benefits for different consumer groups are evaluated against these structural choices. The last section summarises and concludes the article.

\section{RESEARCH METHOD}

The study is based on theme interviews among the key informants around the supply chain of the commerce of grocery goods and related services during the Autumn of 1997. In addition, we analysed the past development paths to the present structure of the trade of daily grocery shopping in Finland.

The key informants were chosen by the researchers based on the following criteria: First, they are related to the commerce of groceries, or related services (e.g., common carriers, upstream food processing industry, ITvendors, and EC-marketplace providers). Secondly, the individuals have been following closely, or are directly responsible for EC in their companies. And finally, they have insight to the current structure and forms of trade in the commerce of grocery goods. The saturation of the information structure of the responses was not used to determine when to cease data collection, because we wanted to cover the whole range of respondents.

We were well received among the professional community: not one of the contacted companies turned down the possibility for an interview. Another implication for the importance of the topic is that most of the interviewees held high rank positions in their organisations. Thus the sample of our respondents represents the views of senior management from various industries related to the commerce of daily grocery goods in Finland. The translated, detailed list of the 33 interviewees from 23 companies $^{6}$ is presented in Appendix A. We also made two test interviews with the help of academic experts on the research topic in order to test and revise the approach, themes, and interview checklist.

The interviewees were sent a list of themes in advance. English translation of the list of themes is in Appendix B. The idea of the first theme was to cover particular cases, or pilots of EC that the interviewees have been following or are currently participating in. We also asked about their current efforts and future plans for EC. The most interesting topics to us were their visions on the trade volume in the near future, and on the segments of potential customers to EC. Any hindrances or critical factors were also covered by the interviews. Finally, we encouraged the interviewees to predict the effects on the industry structure and on the demand of labor in daily shopping and related services, if their estimates would come true.

The interviewers worked mostly in pairs, sometimes in a group of four. The interviewers were the same researchers of the project that planned the questionnaire. The discussions during the interviews were transcribed to text allowing us to develop the measures used to analyse the data.

The texts were circulated and analysed by the interviewers. The answers are tabulated, but as the sample is not random, and the cases are only 23 in number, we did not engage in any statistical analyses. The responses are used to triangulate the theme from various angles of the supply chain.

\section{FINDINGS}

This paper describes grocery, or as it is called in Finland, daily shopping, so that the results can be interpreted in context. It then concentrates on the following four topics: Predictions of the growth of the volume of EC of daily consumer goods in the near future, most potential segments of customers for EC of groceries, and the potential benefits to consumers and suppliers.

\footnotetext{
6 Two producers of grocery goods, seven wholesalers, retailers, trade associations, seven providers of related services (logistics, financing, delivery), and seven IT \& telecommunications solution providers.
} 


\section{Outset of the research - daily shopping in Finland}

Daily consumer goods are defined to be groceries or products with reasonably low unit prices that consumers are accustomed to buy in the same shop (Kasso, 1995). Groceries can be roughly divided into perishables ${ }^{7}$ and nonperishables ${ }^{8}$; nowadays they include also non-food commodities ${ }^{9}$ (LTT, 1981).

In 1996 the industry grew about 3\%, and was about USD 10.31 billion. Hypermarkets continued to increase their market share from 15.6 to $17.8 \%$ (AC Nielsen, 1997) The growth has continued in 1997 (AC Nielsen, 1997), and is expected to stay at 1-2\% per annum until year 2000 (Wires, 1997).

Most of shopping (in terms of volume) is cash-and-carry - there is little delivery of goods to homes. An average purchase ranges from USD 5.5 at corner stores to hundred of USD at shopping centres, with the mean value of the purchase being USD 15 in 1995 (LTT, 1995). The shopping frequency of daily consumer goods is on average 4.6 times a week (LTT, 1997).

The retail of daily consumer goods are classified into nine types of stores as shown in Table 1 (AC Nielsen, 1997).

Table 1. Types of daily consumer goods outlets

\begin{tabular}{|l|r|r|}
\hline Type of store & \% of number of outlets & \% of sales \\
\hline Hypermarkets & $2 \%$ & $18 \%$ \\
\hline Department stores & $2 \%$ & $8 \%$ \\
\hline Large supermarkets & $5 \%$ & $21 \%$ \\
\hline Small supermarkets & $15 \%$ & $25 \%$ \\
\hline Large self-service stores & $21 \%$ & $16 \%$ \\
\hline Small self-service stores & $29 \%$ & $9 \%$ \\
\hline Small stores & $13 \%$ & $2 \%$ \\
\hline Specialised stores & $12 \%$ & $1 \%$ \\
\hline Market halls & $<1 \%$ & $<1 \%$ \\
\hline & $100 \%$ & $100 \%$ \\
\hline
\end{tabular}

Excluded from the table are kiosks, i.e. small convenience stores with unlimited business hours, and gas stations that sell approximately USD 1 billion daily consumer goods per year, accounting for almost to $9 \%$ of the market share (AC Nielsen, 1997).

The commerce of daily grocery goods in Finland is largely similar to other European countries, except that the market is more concentrated, the population in the countryside has become sparser, and the efficiency of logistics has consequently played a major role. These special features deserve closer attention.

The geographical distances have an effect on the cost of logistics, which, by international comparison are quite high (Ministry of Transport, 1994). However, delivery is nowadays more cost efficient, thanks to the development of highly sophisticated routing of transport and efficient logistics within large units. The greater distances are offset by larger units of transport, and less traffic on the roads, as compared to other European countries. For the past three decades the primary trend in Finnish daily consumer goods industry has been to increase the floor-area of the outlets (Koski et al., 1995; LTT, 1996).

Increasing floor-area is very investment intensive, thus the grocery industry is very concentrated as the wholesaler market structure is pure oligopoly: the largest companies directly control the maturity of the market. This concentration has led to an investment race of building massive warehouses and malls at the junctions of motorways, railways, etc., during the 1990's (Koski et al., 1995). This trend in such large scale has no comparison in any other West-European country (Santasalo, 1995).

On the other hand, in 1980 there were almost 10,000 grocery shops in Finland: by comparison, today there are only about 5,000 left, and the number is still expected to drop down to about 4,000 (Pulkkinen, 1998).

Another side effect of the concentration is that it is difficult for an up-stream producer to get into the consumer market: it has to convince the wholesaler about the quality of the product and about its capability to deliver in quantity if required. Also the retailers of the wholesalers are in an awkward position, because the superior efficiency of the big wholesalers' logistics and financial resources are reducing the number of economically feasible alternatives (most often it is the wholesaler who invests in a new store, mall, or shopping center). The bargaining power of the wholesaler does not make life any easier for an individual retailer (Hyvönen, 1990).

\footnotetext{
${ }^{7}$ Perishables are the commodities with shortest shelf-life (e.g., bread, vegetables, fruits, some dairy products, fish). Semi-perishables have longer shelf life, e.g., ready-made, processed food, frozen food.

${ }^{8}$ Non-perishables include canned and dried food stuff, beverages (excluding wines and spirits),

${ }^{9}$ Household products, cosmetics, magazines, tobacco, etc.
} 
The Finnish grocery goods market used to be highly protected and subsidised before joining EU. There were times when the prices were regulated and determined by the state and the farmers' union. After the collapse of Soviet trade and the recession at turn of the decade, the borders opened as Finland joined EU, leading to a rise in imports up to USD 5 billion in 1995. The potential demand for wider assortment and selection of commodities has been satisfied with this increase of import, and the prices of daily commodities to the customer has reduced on the average about $20 \%$. The food processing industry has recovered from the recession, and been able to improve its efficiency and regain the exports especially to Russia, and Baltic countries.

The structural changes and last recession has led to the largest movement of rural people to towns and cities since the 1960 s and $1970 \mathrm{~s}^{10}$. This has also boosted the growth of the retail stores together with the increased mobility of the consumers, motorising of the society. It has also increased levels of consumers' demands and purchasing power as well as industry's strive for rationalisation and the emphasis on price as a means of competition instead of service (Kilpiö \& Pantzar, 1993; LTT, 1996).

Against this backdrop, it is easy to understand the keen interest in the new forms of trade among the suppliers.

\section{Prediction of the growth for EC}

Diffusion of the Internet and the availability of cheap computer equipment has created a new type of customer who wants an easy and convenient alternative to regular shopping in supermarkets (Schuster \& Sporn, 1998). According to a recent study by Andersen Consulting, the number of US households using on-line services to buy food and other household goods and services is expected to grow from fewer than 200,000 now to 15-20 million by 2007 (Kutz, 1998). Our respondents were asked to estimate the volume of electronic commerce of grocery goods within the next few years. The estimates varied, as one could expect, notably. The general impression was, yet, that EC will account for 5-10\% of the total volume of the groceries in 2010. The most optimistic forecasts were found among potential providers of new services to the electronic commerce, and the most moderate among the current retail chain masters who operate also as wholesalers.

These estimates are lower than some other common publicly presented estimates. There are a number of reasons for this: First of all, many of the other estimates are not about some specific sector of trade, thus the object of assessment is simply different. Secondly, the trade of grocery goods is tightly regulated and controlled in terms of preservation and quality of the delivered goods. Despite the advances in packaging and material handling, the logistics are not up to date with the IT-possibilities. And finally, customers find the current delivery channels unproblematic (LTT, 1995), with the only major problem being the limited hours of operation of the grocery stores due to the national legislation. Furthermore, past commentaries on the potential impact of the Internet on consumer marketing have typically failed to acknowledge that consumer markets are heterogeneous and complex and that the Internet is but one possible distribution, transaction, and communication channel in a world dominated by conventional retailing channels. (Peterson et al., 1997).

\section{Potential customer groups}

The Andersen Consulting study identified six major groups of potential on-line grocery shoppers, based upon survey respondents' attitudes toward time, shopping and technology (Kutz, 1998). These groups were Shopping Avoiders, who dislike grocery shopping; Necessity Users, who are limited in their ability to go to the store for some reason; New Technologists, who are typically young and comfortable with technology; Time Starved, who are insensitive to price and will pay extra to free up time on their schedules; Responsibles, who have available time and who get an enhanced sense of self-worth from shopping; and Traditional Shoppers, who are older, avoid technology and genuinely enjoy shopping in a store. All except the traditional shoppers group showed at least some willingness to use on-line grocery shopping services, and most of the groups showed strong interest (Kutz, 1998). These households will represent a wide range of demographics and will spend as much as $\$ 85$ billion on groceries and related purchases through on-line services (Kutz, 1998). An Austrian study identified especially younger and better educated people in urban areas to be more inclined to use online shopping (Schuster \& Sporn, 1998)

The interviewees in our study were asked about potential customer groups for electronic commerce of groceries. A clear tendency of the respondents was to form the consumer groups on the basis of price or time savings, or improved service. The groups below are derived directly from the interviews. Table 2 summarises the expected benefits for each customer segment that was identified.

10 Finland is known for its dispersed population. The situation is changing in cycles. In the 60 's large $44 \%$ of the population lived in the countryside (due to the resettlement after WW2), in the 70's $36 \%$, and at present about $19 \%$ (Statistics Finland, 1997a). Moving from countryside to the cities is partly compensated by the increasing leisure time habitation in the lake district and in Lapland (Statistics Finland, 1997b). 
Table 2. Potential customer groups of electronic grocery shopping

\begin{tabular}{|c|c|c|}
\hline Potential customer groups & Expected benefits & $\mathbf{n}^{*}$ \\
\hline $\begin{array}{l}\text { 1.Sub-urban family commuters } \\
\text { around large cities }\end{array}$ & $\begin{array}{l}\text { reduced time } \\
\text { reduced effort } \\
\text { placing orders independently of time of the day }\end{array}$ & $\begin{array}{l}17: 1 \\
\text { producer } \\
\quad 5 \text { trade } \\
5 \text { related } \\
6 \\
\text { IT\&TC }\end{array}$ \\
\hline 2.Bargain seekers in large cities & $\begin{array}{l}\text { - lower prices } \\
\text { - price comparability }\end{array}$ & 1: 1 trade \\
\hline $\begin{array}{l}\text { 3. Wealthy adults seeking for } \\
\text { high quality services }\end{array}$ & $\begin{array}{l}\text { value added services } \\
\text { - broad selection of special and high quality } \\
\text { products }\end{array}$ & $\begin{array}{l}\text { 2: } 1 \text { trade } \\
1 \\
\text { IT\&TC }\end{array}$ \\
\hline 4.Rural area dwellers & $\begin{array}{l}\text { accessibility of shopping services } \\
\text { - broader selection of products }\end{array}$ & $\begin{array}{l}\text { 5: } 3 \text { related } \\
2 \\
\text { IT\&TC } \\
\end{array}$ \\
\hline $\begin{array}{l}\text { 5.Elderly, or disabled people } \\
\text { relying on social services }\end{array}$ & $\begin{array}{l}\text { - accessibility of shopping services } \\
\text { - broader selection of basic products } \\
\text { - indirect cost savings to the public sector }\end{array}$ & $\begin{array}{l}\text { 12: } 1 \\
\text { producer } \\
\quad 5 \text { trade } \\
4 \text { related } \\
2 \\
\text { IT\&TC }\end{array}$ \\
\hline 6.Computer literate generation & $\begin{array}{l}\text { - first, easy access to the shopping services } \\
\text { - later, same benefits as groups one and two }\end{array}$ & $\begin{array}{l}9: 2 \\
\text { producers } \\
\quad 1 \text { trade } \\
4 \text { related } \\
2 \\
\text { IT\&TC } \\
\end{array}$ \\
\hline $\begin{array}{l}\text { 7.Business-to-business } \\
\text { customers }\end{array}$ & $\begin{array}{l}\text { - } \text { cost savings } \\
\text { - efficiency } \\
\text { - new possibilities for services }\end{array}$ & $\begin{array}{l}\text { 4: } 1 \text { trade } \\
2 \text { related } \\
1 \\
\text { IT\&TC }\end{array}$ \\
\hline
\end{tabular}

- number of mentions by the interviewees (trade $=$ wholesalers, retailers and trade associations; related = logistics, financial and alternative service providers; IT\&TC = IT and telecommunications solution providers)

For the purpose of this paper we will concentrate on the three groups ${ }^{11}$ of customers mentioned by the interviewees (table 2): two most potential groups of customers in the early stage of EGS: sub-urban family commuters and the elderly or disabled, and as third group the bargain seekers in large cities. The third group is, theoretically speaking, the segment that is expected to benefit most from the introduction of EGS, as the customers can get better price and quality information - both from the providers and other consumers as well (Hagel \& Armstrong, 1997). In other words, unlimited information on the web makes price discrimination difficult, if not impossible (provided that there is competition). Yet, on the basis of our interviewees, this kind of benefits to the customers are likely to be realised only later in the diffusion of EGS.

Sub-urban family commuters around large cities

This group consists of working families with strict time constraints. Therefore they are expected to value the new services of electronic commerce in reducing the time and effort needed for daily shopping. Flexible timing in placing the orders via networks, home deliveries, and pick-up terminals would be most useful for them. This was the group that most of the interviewees mentioned first.

Elderly or disabled people relying on social services

Many elderly or disabled people are willing to spend their lives at home. If they can continue living at home, the society saves in costs, because of the decreased need to invest in hospitals and nursery homes. In addition, skilled nurses for this group are in short supply, and they spend a great deal of time taking care of daily tasks of

11 Other groups mentioned in the table 2 are explained in detail in Heikkilä et al., 1998a. 
the nursed. Electronic commerce and related services would increase the capacity of these services significantly (more detailed description of problems of the current infrastructure, alternative service models and benefits, see Heikkilä et al., 1998b). Importance of these issues will grow as the large post-war generation is getting to the age of retirement at the turn of the century.

\section{Bargain seekers in large cities}

The expected late adopter group looking forward to EC is the bargain seekers. This is basically the same group of people taking advantage of the sales and special offers today. This group will become customers of EC only if they can get better prices. Therefore, easy price comparisons, enabled by search capabilities are essential to this group. According to the IT providers these features are technically possible, but for obvious reasons the chain masters do not intend to implement them. Thus, this customer group was discussed in almost all interviews, but rarely considered among the most potential ones.

\section{SERVICES OF EC IN THE DIFFERENT PHASES OF THE CONSUMER'S BUYING PROCESS}

The paper next outlines the consumer buying process of groceries, and then describe EGS from the point of view of the three customer groups: Sub-urban family commuters, bargain seekers, and the elderly and disabled. The paper illustrates the suitability of the EGS-solutions to meet the needs of the specific customer groups and to solve the problems in their current grocery shopping process.

\section{Consumer buying process of groceries}

As a starting point for the interviews we used the six stage consumer shopping process of groceries (Gould, 1997), which differs in many parts from the models describing consumer behaviour in context of selecting a single product. While the traditional models (such as AIDA (see e.g. Kotler et al., 1996)) start with attention and searching information about the desired product or products, the consumer purchasing a basket of groceries makes the planning in a more routine manner and selects the store based on previous experiences, the contents of the basket, the image of the price level, etc. (Wilkie, 1990). However, soon in the interviews it turned out that the model should be amended to cover additional considerations such as the creation of the image of the store, price level information, and recycling.

After the store is decided upon, the current supermarket shopping process for groceries continues step by step basically so that the consumer transports herself to the store, which is in convenient reach on the way home from work, or at the city center. The store has often recycling facilities for paper and board, glassware, cans, etc. She takes a shopping cart, and starts to pick up the foods according to a prepared shopping list, or makes the decisions ad hoc in the store. Most often the customer picks up the goods by herself. Only in special cases the store personnel picks any goods for the consumer. When all the planned and impulse buys have been collected in the cart, the customer goes to the cashier, moves the goods from the cart onto the cashier's table, the cashier reads the optical EAN-stripes. The consumer pays for the goods, normally on debit card, or on credit, and packs them by herself in bags. Finally, the consumer carries the goods home by him/herself, and either starts consuming them or stores them for later use. The steps of the buying process are depicted in table 3 to illustrate some observations on the grocery shopping process.

Based on our interview data, it seems that the process will be changed due to the introduction of the electronic channel. And most strikingly, the chances of splitting supply chain into more specialised parts seems high, which is in contradiction to the predictions of the integrating supply chain (e.g., Benjamin \& Wigand, 1994).

The paper subsequently analyses the shopping process of groceries of the commuters, the bargain seekers, and the elderly in turn, and highlight the potential benefits creating cost savings or value-add to the customers. In the analysis we describe the alternative consumer buying processes for grocery shopping.

\section{Grocery shop services appreciated by the consumers}

The interviewees mentioned services which will be appreciated by the different consumer groups. A clear tendency of the respondents was to. form services that are associated to the consumer groups on the basis of price or time savings, or improved service. The table illustrates this, and is derived from the interviews by the researchers. The consumer groups should be understood more like consumer roles. Consumers may actually be in several roles during their lifetime or even during their weekly life. 
Table 3: Consumer buying process of groceries

\begin{tabular}{|c|c|}
\hline Steps & Observations \\
\hline I. Recognise/identify needs & $\begin{array}{l}\text { In Finland the average weekly visiting rate of grocery store } \\
\text { was } 5.4 \text { in 1980, but has decreased to } 4.6 \text { in } 1994 \\
\text { (A.C.Nielsen, 1994). Ninety percent of the groceries are sold } \\
\text { via self-service retail outlets (A.C. Nielsen, 1997), as many } \\
\text { consider current grocery shopping convenient (Spare \& } \\
\text { Pulkkinen, 1997). }\end{array}$ \\
\hline $\begin{array}{l}\text { 2. Information search and evaluation of } \\
\text { alternatives }\end{array}$ & $\begin{array}{l}75 \text { percent of grocery consumers ignore newspaper ads } \\
\text { before shopping (Wilkie, 1990) }\end{array}$ \\
\hline 3. Make a shopping list & $\begin{array}{l}70 \text { percent of the grocery consumers do not prepare a } \\
\text { shopping list (Wilkie, 1990) }\end{array}$ \\
\hline 4. Choose the grocery store & $\begin{array}{l}\text { Eighty percent of households buy their daily consumer goods } \\
\text { almost always from the same store (Spåre \& Pulkkinen, } \\
\text { 1997), i.e. few buyers choose daily or weekly a different } \\
\text { store. However, price level, service and product range most } \\
\text { important criteria the choice. }\end{array}$ \\
\hline 5. Travel to the chosen store & $\begin{array}{l}\text { About half of the trips to the store are done by car, the other } \\
\text { half is divided into other means, e.g., by foot, public } \\
\text { transport, etc. ( LTT, 1995). }\end{array}$ \\
\hline $\begin{array}{l}\text { 6. Walk in the store, i.e. select and pick up the } \\
\text { goods from the shelves to the cart wait in the } \\
\text { service line, be served by the service } \\
\text { personnel }\end{array}$ & $\begin{array}{l}\text { Over all consumers and products in the supermarket, the } \\
\text { decision times obtained ranged from almost instantaneous to } \\
\text { 5.5.minutes, but almost all purchases were at the low end of } \\
\text { the range (Wilkie, 1990). Up to 30\% of the purchases are } \\
\text { impulse buys (Marjanen, 1997). }\end{array}$ \\
\hline $\begin{array}{l}\text { 7. Operate in the checkout point, i.e. wait in } \\
\text { the line, be served by the cashier, pack } \\
\text { purchases } \\
\text { 8. Payment }\end{array}$ & $\begin{array}{l}\text { Customers find queuing the most annoying thing in current } \\
\text { purchase process (Spåre \& Pulkkinen, 1997). There are more } \\
\text { than one debit card per a Finn. Debit cards are used annually } \\
\text { in } 177 \text { million transactions (Pankkiyhdistys, 1997), private } \\
\text { credit cards in } 50 \text { million transactions (Luottokunta, 1998). }\end{array}$ \\
\hline 9. Transport of the purchases to home & See step 5 above. \\
\hline $\begin{array}{l}\text { 10. Use, maintain, evaluate, feedback } \\
\text { (complaints, return) and dispose or }\end{array}$ & $\begin{array}{l}\text { In Finland } 98 \% \text { of bottles } \\
\text { paper are recycled (Kerä) }\end{array}$ \\
\hline
\end{tabular}

The current Finnish infrastructure seems to meet the needs of the commuters 'customer group'. The needs of the shopping process stages of bargain seekers, however are not as often met, and even less often the needs of the elderly and disabled. The next section discusses the potential benefits of EGS first in general terms, then by the customer groups.

\section{Expected benefits of EGS to the customers}

In the Austrian study the consumers saw the major benefit of online shopping as factors of convenience: possibility to save time and the independence from the store hours were named as major advantages of buying groceries over the Internet. Additionally, the Internet's ability to allow easy comparison of prices and to offer up-to-date product information were appreciated (Schuster \& Sporn, 1998). Generally, the current customers are both expected and willing to pay the extra charges for this convenience (Kalakota \& Whinston, 1997).

The respondents in our study described their expectations about the potential benefits to the customers from electronic grocery shopping. They include direct time and cost savings from improved purchasing processes and better information about the prices and other features of the goods. On the other hand, some of the respondents considered that the customers, or some subset of customers, might be willing to pay for the new value-added services. 
Table 4 Services appreciated by the consumers in the buying process

\begin{tabular}{|c|c|c|c|}
\hline Process Steps & Commuters & Bargain seekers & Elderly and disabled \\
\hline $\begin{array}{l}\text { 1. Recognisefidentify } \\
\text { needs }\end{array}$ & $\begin{array}{l}\text { Family shopping history, } \\
\text { knowledge of lacking } \\
\text { groceries and predicted } \\
\text { need }\end{array}$ & $\begin{array}{l}\text { Methods of planning and } \\
\text { following budget }\end{array}$ & $\begin{array}{l}\text { Local newspapers and } \\
\text { direct mail ads as } \\
\text { information sources. } \\
\text { (these steps are } \\
\text { sometimes done together } \\
\text { with a home helper) } \\
\end{array}$ \\
\hline $\begin{array}{l}\text { 2. Information search } \\
\text { and evaluation of } \\
\text { alternatives }\end{array}$ & Familiarity of the store & $\begin{array}{l}\text { Easy access to price } \\
\text { information of multiple } \\
\text { stores }\end{array}$ & \\
\hline 3. Make a shopping list & $\begin{array}{l}\text { 'Basic' lists and } \\
\text { 'customised' shopping } \\
\text { lists (e.g. recipes) } \\
\text { according to the needs }\end{array}$ & $\begin{array}{l}\text { Shopping lists for several } \\
\text { stores }\end{array}$ & $\begin{array}{l}\text { Familiar products and } \\
\text { previous shopping lists }\end{array}$ \\
\hline $\begin{array}{l}\text { 4. Find source i.e. } \\
\text { choose the grocery } \\
\text { store }\end{array}$ & $\begin{array}{l}\text { Convenient location and } \\
\text { premises, image, quality, } \\
\text { additional services }\end{array}$ & $\begin{array}{l}\text { Price level and distance } \\
\text { (shopping route) }\end{array}$ & $\begin{array}{l}\text { Real choice between } \\
\text { approximate stores (now } \\
\text { the nearest store, or the } \\
\text { one chosen by the } \\
\text { municipality) }\end{array}$ \\
\hline $\begin{array}{l}\text { 5. Travel to the chosen } \\
\text { grocery shop }\end{array}$ & $\begin{array}{l}\text { Ease of access by car, } \\
\text { good parking facilities }\end{array}$ & $\begin{array}{l}\text { Easy access either by car, } \\
\text { by foot or by public } \\
\text { transportation }\end{array}$ & $\begin{array}{l}\text { Easy access by foot } \\
\text { (sometimes the shopping } \\
\text { is done by the home } \\
\text { helper on behalf of the } \\
\text { person) }\end{array}$ \\
\hline $\begin{array}{l}\text { 6. Select and pick up } \\
\text { the goods from the } \\
\text { shelves to the cart, } \\
\text { getting served by the } \\
\text { personnel at service } \\
\text { counters }\end{array}$ & $\begin{array}{l}\text { Alternative routes through } \\
\text { the store according to the } \\
\text { shopping situation (e.g. } \\
\text { with/without kids) }\end{array}$ & $\begin{array}{l}\text { Clearly visible guidance } \\
\text { like product group signs, } \\
\text { price tags, sales offers } \\
\text { and other in store } \\
\text { information. }\end{array}$ & $\begin{array}{l}\text { Prefer service to picking } \\
\text { up. If no help in picking, } \\
\text { short routes through the } \\
\text { basic supplies }\end{array}$ \\
\hline $\begin{array}{l}\text { 7. Operate in the } \\
\text { checkout point, i.e. } \\
\text { wait in the line, be } \\
\text { served by the cashier, } \\
\text { pack purchases } \\
\text { 8. Payment }\end{array}$ & $\begin{array}{l}\text { Short queuing times, help } \\
\text { in packing } \\
\text { Multiple payment } \\
\text { methods, i.e., cash, credit } \\
\text { cards, debit cards, and } \\
\text { credit account. }\end{array}$ & $\begin{array}{l}\text { Cash and credit card } \\
\text { availability }\end{array}$ & $\begin{array}{l}\text { Help in packing } \\
\text { Cash and credit account }\end{array}$ \\
\hline $\begin{array}{l}\text { 9. Transport of the } \\
\text { purchases to home }\end{array}$ & $\begin{array}{l}\text { Short distance and easy } \\
\text { access to the parking } \\
\text { facility }\end{array}$ & Easy access (see step 5) & Home delivery services \\
\hline $\begin{array}{l}\text { 10. Use, maintain, } \\
\text { evaluate, feedback } \\
\text { (complaints, retum) } \\
\text { and dispose or } \\
\text { recycle }\end{array}$ & No data available & No data available & No data available \\
\hline
\end{tabular}

\section{Time savings}

The reduction of time and effort are expected to be the most obvious benefits to the customer thanks to EC of groceries. Consumers save time and have more control because they can shop from home or work whenever they want (e.g. Kalakota \& Whinston, 1997). All interviewees mentioned time savings as a major benefit. These savings will be achieved in the forms of shorter ordering time, reduced need for commuting, and reduction in time spent in picking up the products and the payment of them.

\section{Cost savings}

The tremendous growth of the Internet and the WWW is bringing significant changes to the economics of marketing and is likely to lower prices for retail consumer products (Lee, 1998). Consumers can save money, despite the extra overhead, because they can do better comparison shopping, and buy fewer impulse items than 
they would if they shopped at a real supermarket (Alba et al, 1997; Hoffman et al, 1996; Kalakota \& Whinston, 1997). By lowering the cost of searching for alternative and substitute products in a commodity-like bargaining atmosphere, electronic markets encourage greater price competition for relatively generic products (Elofson \& Robinson, 1998; Lee, 1998). Nevertheless, with the advent of systems such as Bargainfinder (which searched for lowest-priced CDs on the Web) some suppliers have quickly responded by making their formats difficult to search in order to prevent price-shopping (Elofson \& Robinson, 1998).

Interviewees believed that the cost savings can be achieved by gaining access to better information on the prices of the daily basket of groceries, and consequently, from keener price competition. Price decline can also be due to the avoidance of some part of the present cash-and-carry logistics. In addition, lower total expenditure on grocery goods can be achieved also indirectly by getting better control on consumption with the information gathered and reported by the shop keeper, or an agent. Many of the interviewees could not imagine the breakthrough of EGS until the costs will drop to the level of traditional shopping. Most of the current online consumers are, however, described as being interested in making better-informed purchases more quickly, rather than necessarily getting the lowest price (The Economist, 1997).

\section{Value added services in planning, selecting and placing orders}

EGSs can offer a variety of value added services for planning, executing and placing the orders that are new to the current shopping process. Shoppers can browse through virtual aisles based on the way they want to shop, searching for foods offered as specials or scanning the dairy counter (Kalakota \& Whinston, 1996). Within categories, customers can choose to have the items arranged alphabetically by brand or sorted by lowest cost per ounce, package size, unit price, or nutritional value (Choi, et al., 1997). These services may also include advanced facilities for information processing to make planning for shopping more effective, such as ready-made shopping lists, or capability of building a personal shopping list for one-shot or repeated ordering (Kalakota \& Whinston, 1997). Moreover, recipes can be turned to shopping lists according to the number of persons joining the meal.

If the supply of electronic commerce develops as expected, far more exhaustive selection of goods than in the traditional shopping environment is also available to the consumers through the electronic channel. There is potential of wider availability of hard-to-find products and wider selection of items due to the width and efficiency of the channel (Hoffman et al, 1996). In 1966, the number of articles in a selection of an average store was 2600, in the beginning of the 1990's 6100. Today in a Finnish hypermarket there are on average about 10000 to 12000 articles (daily consumer goods; all products included about 20000 articles), in Germany about 15000 , and in the United States up to 25000 (Kilpiö and Pantzar, 1993). Clearly presented special offers and possibilities to price comparisons between competing stores will provide opportunities to cost savings, at least in theory.

\section{Time and place independence}

EGS provides consumers with new and enhanced abilities to shop anywhere, anytime, and any place (Sherman \& Topol, 1996). Ordering can be done from distant places around the clock. Many alternative stores are accessible, which makes it possible to order the bundle to a local store close to a remote location (e.g., a summer cottage).

\section{New forms of delivery}

In the early stage of EGS, two forms of delivery are used: home delivery or picking up from the store. These forms do not serve all customers well and therefore new solutions, like drive- in-type pick up terminals, neighbourhood pick up stations (perhaps in the connection with a small convenience store or gasoline station) or unmanned low temperature storage facilities outside the apartments, should be developed in the future.

\section{Benefits for the three selected customer groups}

As illustrated by the literature excerpts and expert opinions above, electronic channels are expected to create new opportunities to serve and create value-added to the customers. Ultimately, it can provide wide selection at low prices $\mathbf{2 4}$ hours a day. However, the specific features are not equally important for every consumer groups, as is implied already in table 4 . Therefore, there is a need to systematically evaluate the importance of the service features

The customer segment that values most of the time saving is the commuters. This is natural as their families are typically in an active stage of life; parents working full time and children participating in leisure activities. Thus, travelling to the store has never been a problem for them, as they are commuting and taking their children to their activities. The shorter and time independent ordering time are highly valued, if the ready made bundle of groceries can be conveniently picked up (saving the burden and time of selecting and picking up the goods). 
Home deliveries are actually not so important, as the time window of the delivery is difficult to synchronise to family activities. Costs and cost control are important, but not the primary issue, as the needs and search for variety are driving to the shop. Thus customised shopping lists, or lists created from recipes are of interest to them, which eventually also means the need for broader selection.

For the bargain seekers a more planned approach to shopping is needed to keep the grocery expenses under control. Thus, they value the information facilities that help in planning, comparing prices, and finding special offers from a number of stores are high. Ordering in advance is not the primary issue, as they are willing to do the legwork of getting to the stores, picking up the sales goods, packing and taking them back to home by themselves. As a consequence, home delivery may not be valued by them either, particularly if it presents an additional cost item.

The elderly and disabled form a two faceted group, as they can be self-supporting or in need of help (temporary or permanent). The current infrastructure of grocery shopping does not meet their needs of proximity, service, and trusted relationship at a favourable price. Thus, if they are able to do the shopping by themselves, they would appreciate both customised and standard shopping lists and prefer home delivery to other means of getting the basket of purchases. Service and trust is often more important than money, but a credit account is preferred.

But if the customer is relying on community help, the situation is different. Currently, the customer is authorising the home helper to do shopping for him. With the help of EGS they can together plan and order the goods online either to be delivered to home, or being picked up by home helper, or a trusted third party, e.g., by coupling it to the meal services. There is no need to hand over the cash to the home helper for shopping, and the electronic channel can provide a feedback channel about the service and quality of products. Thus, in this case the customer can benefit indirectly from the time savings of the home helper, who can then spend more time with the elderly instead of doing shopping. This would also mean the possibility to get a real choice of the store; currently it is normal that the authorities make a long-term contract with a local entrepreneur.

But how can these benefits realised, if the suppliers are transforming to EGS? In the following section we depict suppliers' structural and strategic view on EGS.

\section{SUPPLIERS STRATEGIES AND INFRASTRUCTURE ALTERNATIVES}

As consumers grow accustomed to using on-line services for ordering groceries and related purchases, traditional retailers and manufacturers will face pressure to adapt to changing consumer demands (Kutz, 1998). In this section it is outlined how the strategies of the electronic grocery stores are derived from the benefits to the supply chain estimated by interviewees. The strategies can be based roughly on two categories of infrastructure: those which could be realised on top of the current bricks-and-mortar retail structure (e.g. during the transition period), or on building on new structural solutions and capabilities of the supplier. The respondents discussed the advantages of EC in the present situation and then moved on to their vision on what the advantages might be in the future. These are documented in detail in Kallio et al., 1997.

\section{Infrastructure alternatives for EGS}

\section{EGS based on current infrastructure}

One advantage for current retailers revealed by the Andersen Consulting study is consumers desire for their current, primary grocery stores to also be their EGS providers - simply because they prefer a name they know and trust. This advantage will not last long, however, as today's emerging consumer direct providers become more established (Kutz, 1998). When EGS is based on either existing hypermarket, supermarkets, retail, or even wholesale outlets, only the virtual marketplace is created in the electronic network. The upstream logistics remain mostly the same all the way down to the retail outlet, where part of the personnel has to be dedicated to picking, packing and delivering the goods, which may actually help in leveling the use of labor during the workday. Some parts of this work can be outsourced as well.

However, in this structure there will be some redundant work: the goods are first stored in the shelves of the store or wholesale outlet, from where the personnel collects them for further delivery to the customer. This manner means additional costs to the retailer and consequently higher prices, or at least the fees for delivery, to the customers. Building electronic commerce using the current infrastructure as a platform means that aside from improved leveling of resources and shop floor utilisation the advantages can be achieved primarily by enhanced marketing and improved information on purchasing behaviour.

\section{Dedicated EGS infrastructure}

A dedicated EGS requires totally new design of the logistics system and layout of the store. This is because the current infrastructure is built on customer self-service, and the stores are to attract customers for impulsive buying. They are not suitable for efficient pick-up as such. 
It became obvious during the interviews that the current delivery channels of groceries cannot realise the potential of EGS. According to our respondents, there seem to be opportunities emerging for new forms of logistics at warehouses (for packing, loading, pricing, collecting and paying), and at retail outlets. EC will also bring along new types of home delivery services. New dedicated platforms are expected to emerge as a basis for a new infrastructure. For the major players in the industry there are possibilities to win new markets and customers without sacrificing performance.

It seems evident that building EGS on the current infrastructure is a short term solution for the transition period before more efficient logistic solutions. Only dedicated solution can hope to meet simultaneously all the prerequisites of large scale EGS, i.e., lower prices, wider selection, and around-the-clock opening hours. In a large enough solution also non-technically oriented consumers can be served by providing different order and delivery channels, e.g. call centers, or fax order services.

\section{Differences of EGS structures from the customers' point of view}

Time, and to some extent also place independence are distinctive features of EGS. Both EGS infrastructure solutions represented above can offer the same benefits in terms of reduced time and effort in shopping: ordering times are shorter, there is no need to travel to the store and no time is spent in collecting the goods and queuing at the cashier's desk. Home (or office) delivery is, at least so far, the only delivery choice in the existing EGSs. With a dedicated structure other types of solutions, such as drive-in-type pick up terminals or manned or unmanned pick up terminals or facilities can be built more efficiently. This option would be particularly useful to the time pressed commuters.

New value adding services to aid in planning, such as standard and customised shopping lists, recipe services, additional information on nutritional values, are key features in EGS, regardless of the infrastructure solution. In addition, independently of the infrastructure solution, the consumer can gain better control on the costs of grocery shopping with EGS. The total cost of a basket of groceries, however, can be less than in a traditional brick-and-mortar shop only in a dedicated EGS solution, within which the extra costs of inefficient logistics can be eliminated. Lower costs are particularly valued, by definition, by the bargain seekers, as well as at least by some of the elderly and disabled. The commuters are likely to be less sensitive to the price differences.

There is, nonetheless, a major difference in the number of products in the selection. In an EGS built on top of an existing outlet, the selection is smaller or at the most it can be as large as in the traditional store, whereas in the dedicated structure the potential selection can be significantly broader. The broad selection is valued especially by the commuters, as well as some of the elderly and disabled.

Thus, it seems that there is a need for the new dedicated EGS solution in order to serve different consumer groups. When electronic commerce diffuses more in grocery markets with large numbers of buyers and sellers, it can improve the welfare of both the sellers and the buyers by increasing market efficiency, rather than transferring welfare from sellers to buyers. (Lee, 1998). In our opinion, in a competitive environment this calls for the efficiency increase in logistics of the value-added services (pick-up, delivery) suggested by the dedicated structure.

\section{SUMMARY AND CONCLUSIONS}

This analysis of the potential for electronic commerce of groceries is based on theme interviews of 33 people in 23 organisations in Finland during the Autumn of 1997.

The specific areas of interest of the study were the predicted volume of EC in grocery shopping, the most potential customer segments, and the anticipated benefits of EC to customers and suppliers.

The key findings indicate that the interviewees estimate the EC of grocery goods to reach 5-10\% of the total volume within the next twelve years (estimates varying, however, between $2 \%$ and $20 \%$ ).

The most potential groups of customers in the early stages of EC of groceries are likely to be found among suburban family commuters, elderly and disabled people, and computer literate youth. The rural area dwellers, high-income middle-aged people and some business customers (e.g., commercial and public catering units, small restaurants, grills) were also mentioned. The differences between respondents' views of the potential groups are, however, obvious.

Basically, the anticipated benefits to the customers are savings in the current shopping time and effort, new value-added services or lower prices. Those operating in a direct customer contact emphasise the first two, and service providers see also lower prices as a driving force. Yet, only few respondents mentioned the bargain seekers as the beneficiaries of EC. The emergence of value-added services and lower prices are evidently subject to fundamental changes in EC platforms, logistics and market structure; not to a simpler delivery chain as suggested by the literature, but more complex chain of value-added service providers.

If, in the near future, the customer orders would be received electronically, the information systems for grocery shopping could be integrated to the current supply chain. This would complement the current logistic processes of collecting and delivering the goods. The rationalism for this development path lies in the fact that grocery 
industry in Finland resembles an oligopolistic market giving the major players such a strong bargaining power, that it is extremely difficult for the new entrants to enter the market, or outperform the chain masters in efficiency. In addition, as the current retail chains would not gain from rapidly changing structure, the modest growth and conservative development of EC in the grocery industry is easy to understand.

As soon as customers gain experience in electronic shopping, they are likely to call for better services and lower prices despite the demanding logistics involved in grocery shopping. By then, it is most probable that software for price comparisons between electronic grocery shops will appear. Furthermore, the demands of the numerous segments of potential customers are different, or even contradictory. Polarisation of markets might follow, i.e. we may have bigger chain masters than ever, but on the other hand there is substantial potential for a decentralised market structure, especially concerning logistics, retail outlets, and value-added services. If the current grocery chain masters developed the dedicated electronic grocery shops, they would end up cannibalising their own shop-keepers. Possible developers of these dedicated electronic channels could be small regional or local entrepreneurs or a big international chain with its own procurement sources and good reputation to attract and convince the consumers. Given the existing infrastructure and the forecasted $10 \%$ share of the daily shopping for $\mathrm{EC}$ is an incentive high enough to attract various investors into EC-development within the next years.

\section{ACKNOWLEDGMENTS}

The authors wish to thank Ministry of Trade and Technology Development Centre (TEKES) for financial support, and the organisations for their willingness to participate in the interviews.

\section{REFERENCES}

AC Nielsen (1997) Newsletters 1/97.

Alba, J., Lynch, J., Weitz, B., Janiszewski, C., Lutz, R., Sawyer, A. \& Wood, S. (1997) "Interactive Home Shopping: Consumer, Retailer, and Manufacturer Incentives to Participate in Electronic Marketplaces", Journal of Marketing, July, Vol 61, pp 38-53.

Benjamin, R. I \& Wigand, R. (1994) "Electronic Markets and Virtual Value Chains on the Information Superhighway", Sloan Management Review, Winter 1994, pp 62-72.

Choi S.-Y, Stahl D.O. \& Whinston A.B. \& (1997) The Economics of Electronic Commerce. The Essential Economics of Doing Business in the Electronic Marketplace, Macmillan Technical Publishing, Indianapolis, IN., USA.

The Economist May $10^{\text {th }} 1997$, pp 3-26.

Elofson. G. \& Robinson, W.N. (1998) "Creating a custom mass-production channel on the Internet", Communications of the ACM, March, Vol. 41, No. 3, pp 56-62.

Gould, J. \& Silberzahn, P. (1996) Electronic Home Shopping, A review of evidence and expert opinion from the USA and UK, Centre for Marketing Working Paper, London Business School, No. 96-802.

Hoffman, D.L., Novak, T.P. \& Chatterjee, P. (1996) "Commercial Scenarios for the Web: Opportunities and Challenges", Journal of Computer-Mediated Communication, Vol 1., No. 3

Hyvönen, S. (1990) Integration in Vertical Marketing Systems: A Study on Power and Contractual Relationships between Wholesalers and Retailers, Doctoral Dissertation, Helsinki School of Economics, series A:72.

Hagel, J., and Armstrong, A., (1997) Net Gain: Expanding Markets Through Virtual Communities", Harvard University Press, USA.

Heikkilä J., Kallio J., Saarinen T., and Tuunainen V., (1998a) "Diffusion of Electronic Grocery Shopping: Expectations of current suppliers and potential service providers in Finland", in the proceedings of the 6th European Conference on Information Systems, June 4-6 1998, in Aix-en-Provence, France, Baets W.R.J., (editor), University of Aix-Marseille III, Vol. I, pp 218-232.

Heikkilä J., Kallio J., Saarinen T., and Tuunainen V.K., (1998b) "EC of groceries for elderly and disabled: Comparison of alternative service models", in the proceedings of the 21st Information systems research seminar in Scandinavia, 8-11 August, Sxby Søbad, Denmark, Buch, N.J., Damsgaard, J., Eriksen, L.B., Iversen, J.H. \& Nielsen, P.A. (Eds.), Department of Computer Science, Aalborg University, Vol 1, pp 337350.

Kalakota, R. \& Whinston, A.B. (1996) Frontiers of Electronic Commerce, Addison-Wesley Pub Co.

Kalakota, R. \& Whinston, A.B. (1997). Electronic Commerce, A Manager's Guide. Addison-Wesley.

Kallio J., Saarinen T. \& Tuunainen V.K. (1997) "Elektroninen kaupankäynti päivittäistavarakaupassa Potentiaaliset kuluttajaryhmät, jakeluratkaisut, rakenteet ja työllisyysvaikutus (Electronic Commerce in Grocery Shopping - Potential consumer groups, forms of delivery, structures and employment effects)", LTT Series B 137, Helsinki (in Finnish). 